\title{
Cultural Resources Report for the Cane Island Branch Section of the Buffalo Bayou Project Between Katy-Flewellen Road and Kingsland Boulevard in Fort Bend County, Texas
}

Robert Krause

James Hughey

Jacob Hilton

Follow this and additional works at: https://scholarworks.sfasu.edu/ita

Part of the American Material Culture Commons, Archaeological Anthropology Commons, Environmental Studies Commons, Other American Studies Commons, Other Arts and Humanities Commons, Other History of Art, Architecture, and Archaeology Commons, and the United States History Commons

Tell us how this article helped you.

This Article is brought to you for free and open access by the Center for Regional Heritage Research at SFA ScholarWorks. It has been accepted for inclusion in Index of Texas Archaeology: Open Access Gray Literature from the Lone Star State by an authorized editor of SFA ScholarWorks. For more information, please contact cdsscholarworks@sfasu.edu. 


\section{Cultural Resources Report for the Cane Island Branch Section of the Buffalo Bayou Project Between Katy-Flewellen Road and Kingsland Boulevard in Fort Bend County, Texas}

Creative Commons License

\section{(c) (1) (9)}

This work is licensed under a Creative Commons Attribution-NonCommercial 4.0 International License 


\section{GRAY \& PAPE} HERITAGE MANAGEMENT
Cultural Resources Report for the Cane Island Branch Section of the Buffalo Bayou Project Between Katy-Flewellen Road and Kingsland Boulevard in Fort Bend County, Texas

\section{LEAD AEENCY:}

Natural Resource

Conservation Service

Texas Antiquities Permit Number 9319
PREPARED FUR: BIO-WEST, Inc. 1018 Frost Street Rosenberg, Texas 77471

\section{PREPARED BY:}

Gray \& Pape

110 Avondale Street Houston, Texas 77006 


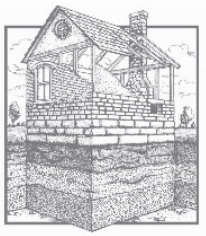

\section{GRAY $\&$ PAPE \\ HERITAGE MANAGEMENT}

Project No. 20-72306.001

Cultural Resources Report for the Cane Island Branch Section of the Buffalo Bayou Project Between Katy-Flewellen Road and Kingsland Boulevard in Fort Bend County, Texas

Lead Agency:

Natural Resource Conservation Service

Texas Antiquities Permit Number 9319

Prepared for:

BIO-WEST, Inc.

1018 Frost Street

Rosenberg, Texas 77471

Prepared by:

Robert Krause, Ph.D.

James Hughey, M.A., RPA

And Jacob Hilton

Gray \& Pape, Inc.

110 Avondale Street

Houston, Texas 77006

(713) $541-0473$

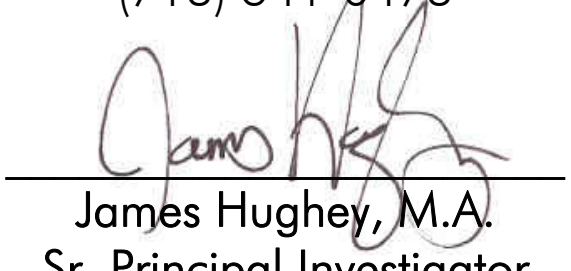

Sr. Principal Investigator

May 28, 2020 


\section{ABSTRACT}

Gray \& Pape, Inc., of Houston, Texas, under contract with BIO-WEST, Inc., has prepared the following report on cultural resources management activities in Fort Bend County, Texas. The project includes an archaeological survey of a total of approximately 0.93 kilometers $(0.58$ miles) along Buffalo Bayou between Katy-Flewellen Road and Kingsland Boulevard in Katy, Texas. The archaeological Area of Potential Effects is defined as the maintenance corridor, 30 to 60 meters (98 to 196 feet) long. The goal of this study was to assist Fort Bend County, the Texas Historical Commission, and the lead federal agency in determining whether or not intact cultural resources are present within areas for construction, and if so to provide management recommendations for these resources. All activities described herein were subject to Section 106 of the National Historic Preservation Act and issuance of an Antiquities Permit for Archeology (Permit 9319) applied for by Gray \& Pape, Inc. on February 13, 2020, and issued by the Texas Historical Commission. No diagnostic or non-diagnostic artifacts were collected in the course of the current survey. As a project permitted through the Texas Historical Commission; however, Gray \& Pape, Inc. submitted project records to the Center of Archaeological Studies at Texas State University. The Natural Resource Conservation Service is the lead federal agency for the project.

Fieldwork was conducted between March 12 and March 16, 2020 and required approximately 40person hours to complete. Subsurface testing included a combination of systematic shovel testing and judgement sample auger probing. The site file research revealed two previously recorded archaeological sites (41FB101 and 41FB102) are located within the project area. At the beginning of the survey, an initial attempt was made to relocate previously recorded Sites 41FB101 and 41FB102 through surface inspection and limited shovel testing across the Area of Potential Effects along both sides of Buffalo Bayou. Recent disturbances from mechanical excavation along the channel slopes, the dumping of spoil across the surface of the two-track right-of-way along the bayou, and the active installation of sheet piling were photographed and mapped. Sites 41FB101 and 41FB102 could not be relocated within the Area of Potential Effects during the surface inspection, shovel testing or auger probing. No other historic or prehistoric artifacts or cultural features were identified as a result of this survey.

During the initial reconnaissance, Rangia shells $(n=8)$, including whole (closed) specimens and half shell, were observed on the surface in an area recently disturbed by heavy machinery. The shells were located east of Site 41FB101 along the two-track right-of-way and slope of the east bank of Buffalo Bayou. The majority of them were smaller than 3 centimeters (1.2 inches), with one whole specimen measuring approximately 6 centimeters $(2.4$ inches). Surface and subsurface inspection in the immediate area of these specimens failed to find evidence of associated cultural features or artifacts on the surface or in a buried context. A variety of modern bricks and brick fragments were also observed along the inner slopes of the east bank near the shell scatter. These same materials were later observed among the variety of riprap materials along the west bank of the bayou west of Site 41FB102 near a residential property immediately adjacent to the Area of Potential Effects. No additional cultural materials were observed on the surface with the exception of modern debris including plastics and aluminum cans.

Gray \& Pape, Inc. is not recommending a site designation for the Rangia shell or brick scatter observed during the survey for the foregoing reasons: 1) there were no intact, buried deposits or features found; 2) there was no material that could be positively identified as artifacts; 3) the bricks observed were modern and likely deposited by landowners in attempts to prevent erosion; 4) the size, quantity, and inclusion of whole Rangia identified on the surface appear to be natural occurrences as opposed to the 
remains of an archaeological deposit or feature; and 5) it is impossible to determine the original location of the shell specimens at this time.

Based on the results of this investigation, Sites $41 \mathrm{FB} 101$ and 41FB102 do not appear to extend into the existing easement belonging to the Fort Bend County Drainage District. Instead, both sites appear to be located on private property outside of the project Area of Potential Effects. As such, these sites have not been evaluated for National Register eligibility, but Gray \& Pape, Inc. recommends that there will be no direct impact to these sites. It is also recommended that because the majority of project impacts will occur within sediments that have been repeatedly impacted by past channelization activities, the potential to identify intact, significant cultural resources is low. Gray \& Pape, Inc. recommends the project be allowed to proceed as currently planned. As a protective measure during construction, highvisibility temporary fencing should be installed against the edge of the Area of Potential Effects in the vicinity of the two known sites. No additional cultural resources activities are recommended unless project plans change. 


\section{TABLE OF CONTENTS}

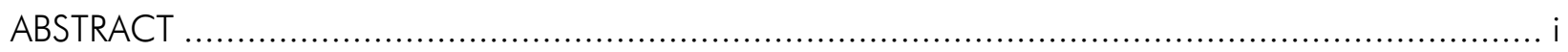

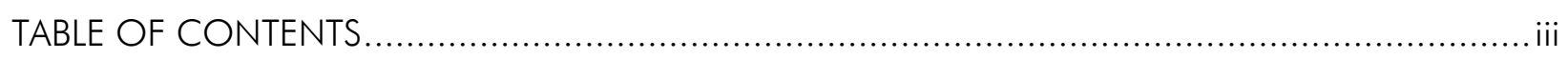

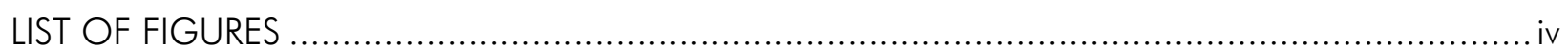

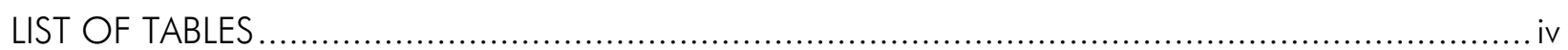

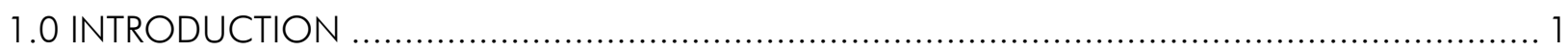

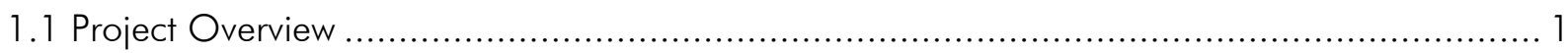

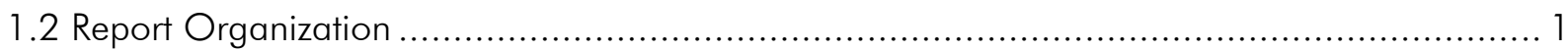

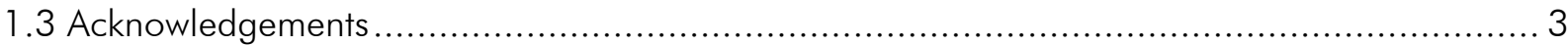

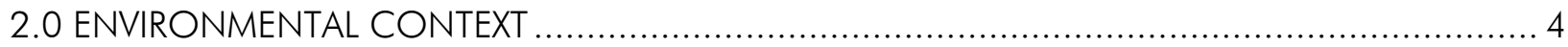

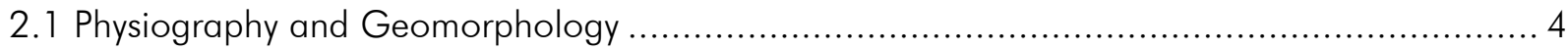

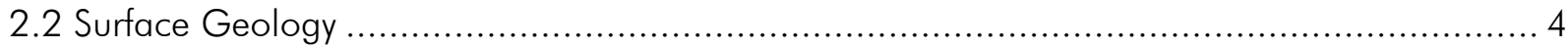

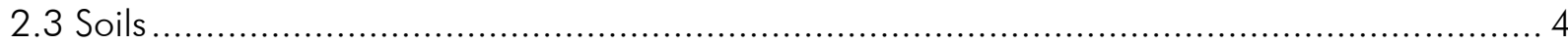

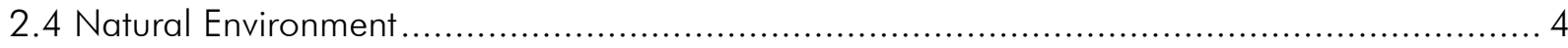

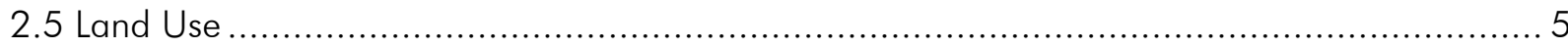

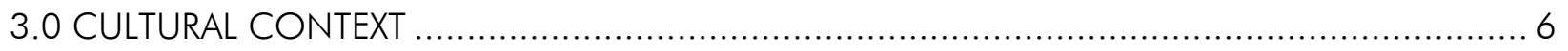

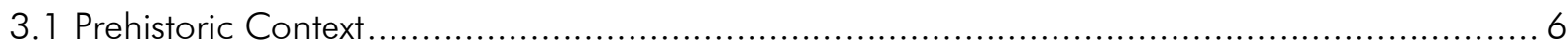

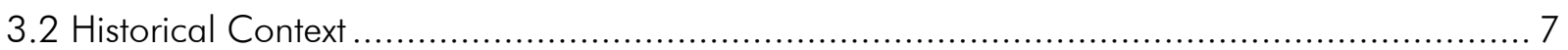

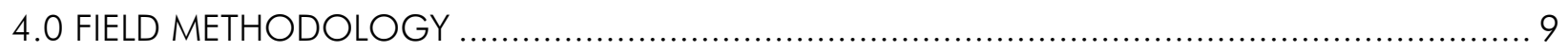

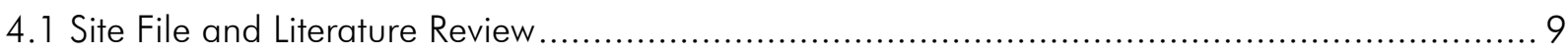

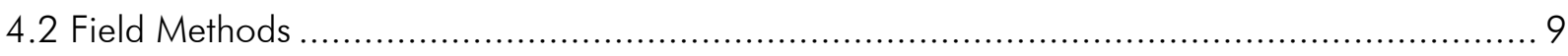

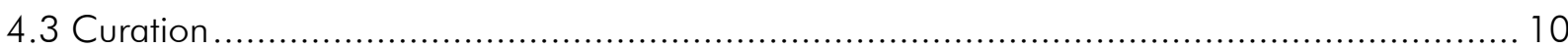

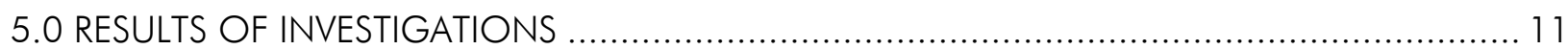

5.1 Result of Site File and Literature Review............................................................... 11

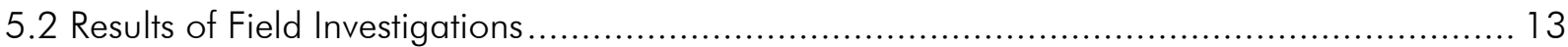

6.0 CONCLUSIONS AND RECOMMENDATIONS ....................................................... 19

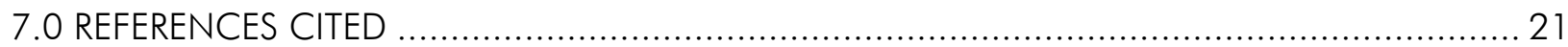

APPENDIX: Shovel Test Log 


\section{LIST OF FIGURES}

Figure 1 - 1. Cane Island Branch project area in Fort Bend County, Texas ................................... 2

Figure 5-1. Project area with field survey results........................................................ 14

Figure 5-2. Representative shovel test profiles........................................................ 15

Figure 5-3. Recent disturbance and construction along Buffalo Bayou near shell scatter, view is facing

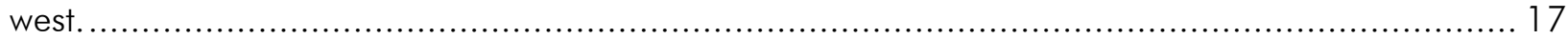

Figure 5-4. Residential property and riprap along Buffalo Bayou, view is facing southwest. ............ 17

Figure 5-5. Overview of Site $41 \mathrm{FB} 101$ centroid location beyond silt fencing. View is facing east. .... 18

Figure 5-6. Overview of riprap along channelized bayou and Site 41FB102 centroid. View is facing southeast.

\section{LIST OF TABLES}

Table 2-1. Soils Recorded within the APE. 4

Table 5-1. Previously Recorded Archaeological Projects Surrounding the Cane Island Branch Section of the Buffalo Bayou Project, Fort Bend County, Texas

Table 5-2. Previously Recorded Cultural Resources Surrounding the Cane Island Branch Section of the Buffalo Bayou Project, Fort Bend County, Texas. 


\subsection{INTRODUCTION}

Gray \& Pape, Inc. (Gray \& Pape), of Houston, Texas, under contract with BIO-WEST, Inc. (BIO-WEST), has prepared the following report on cultural resources management activities in Fort Bend County, Texas. All activities described herein were subject to Section 106 of the National Historic Preservation Act (NHPA) and issuance of an Antiquities Permit for Archaeology (Permit 9319) applied for by Gray \& Pape on February 13, 2020 and issued by the Texas Historical Commission (THC). The Natural Resource Conservation Service (NRCS) is the Lead Federal Agency for the project.

\subsection{Project Overview}

The project area is located on the Katy, TX 7.5minute United States Geological Survey (USGS) topographic quadrangle map in Fort Bend County, Texas (Figure 1-1). The scope of work for the project includes an archaeological survey of a total of approximately 0.93 kilometers (0.58 miles) along Buffalo Bayou between Katy-Flewellen Road (Rd.) and Kingsland Boulevard (Blvd.). Based on conversations with BIO-WEST, construction will be limited to the Fort Bend County Drainage District easement which measures 10 meters (35 feet) from the centerline of the channel on the upstream area and 15 meters (50 feet) from the centerline on downstream. The proposed work consists of what should be considered maintenance work; there will be no change in land use and the existing ditch dimensions will not exceed the original engineering design of the improved drainage ditch. No increase in total capacity will occur as a result of this work nor will work-related activities impair the flow or circulation of waters of the United States or reduce the reach of such waters. The maintenance work proposed is designed to restore flow and circulation to the original engineering design of the improved ditch, while meeting safety requirements for continued maintenance. Work will consist of excavation of sedimentation and installation of sheet-piling to restore bank contours. In areas with sheet-pile wall placement, sheet-piling will be placed outside of the jurisdictional limit of Buffalo Bayou. Sheet piling will be driven no deeper than 4.57 meters (15 feet) below the natural ground surface. The maintenance corridor will be 30 to 60 meters (98 to 196 feet). These dimensions define the archaeological Area of Potential Effects (APE). The goal of this study was to assist Fort Bend County, the THC, and the lead federal agency in determining whether or not intact cultural resources are present within areas for construction, and if so to provide management recommendations for these resources.

\subsection{Report Organization}

This report is organized into seven numbered chapters and one lettered appendix Chapter 1.0 provides an overview of the project. Chapter 2.0 presents an overview of the environmental setting and geomorphology. Chapter 3.0 presents a discussion of the cultural context associated with the APE. Chapter 4.0 presents the research design and methods developed for this investigation. The results of this investigation are presented in Chapter 5.0. Chapter 6.0 presents the investigation summary and provides recommendations based on the results of field investigations. A list of literary references cited in the body of the report is provided in Chapter 7.0. A table of all shovel test and auger probe data is provided in the appendix. 


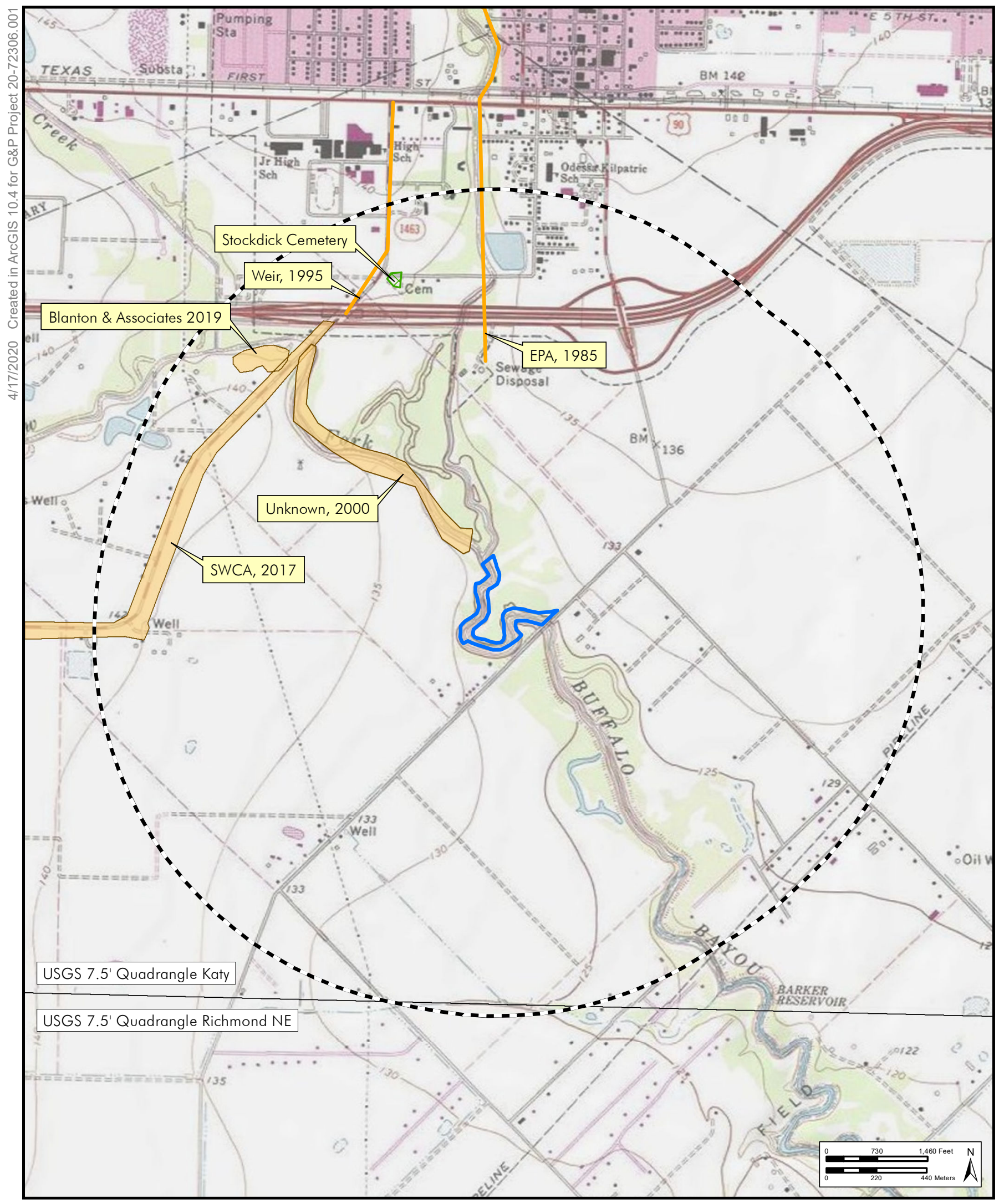

Figure 1

Project area location in Harris County, Texas.

GRAY \& PAPE HERITAGE MANAGEMENT $\square$ Project Area

. - Study Radius (1.6-km/1-mi.)

$\triangle$ Previously Recorded Cemetery Boundary

$\square$ Previously Recorded Area Survey

- Previously Recorded Linear Survey

$\square$ USGS Quadrangle Boundary

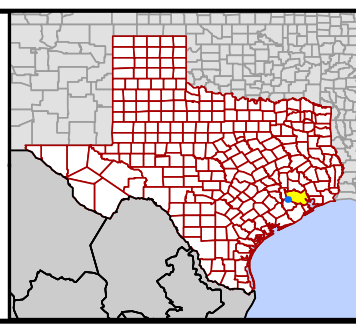




\subsection{Acknowledgements}

Fieldwork was conducted between March 12 and March 16, 2020 and required approximately 40-person hours to complete. Field activities were conducted by Senior Principal Investigator James Hughey, M.A., RPA, Senior Principal Investigator Tony Scott, M.A., and Archaeologist Jacob Hilton. The report was prepared by Robert Krause, Ph.D., James Hughey, and Jacob Hilton. Graphics were produced by Duncan Hughey. Jessica Bludau edited and produced the report. 


\subsection{ENVIRONMENTAL CONTEXT}

\subsection{Physiography and Geomorphology}

Fort Bend County lies within the Gulf Coastal Prairie region of Texas. It is a generally flat plain, with small areas of timbered bottomlands (Mowery et al. 1960). Topographic relief is the result of down cutting of sediments from fluvial action associated with the many rivers, bayous, and creeks within and around Fort Bend County. Major drainages include the Brazos River to the west, the Colorado River to the north, and the San Jacinto River to the east. Buffalo Bayou is spring-fed and originates in Waller County, flowing west to east, through Houston, and draining into the San Jacinto River.

\subsection{Surface Geology}

Geologically, the APE is underlain by the Lissie Formation, a Pleistocene-Age deposit of clays, silts, and sands, with few gravels (Barnes 1982). The Lissie Formation is the interval between the Willis and Beaumont Formations at a subsurface level. Glacial-interglacial cycles have heavily influenced Lissie deposition (Young et al. 2010).

\subsection{Soils}

There are two different soils mapped within the APE (Table 2-1) (Soil Survey Staff, Natural Resources Conservation Service, United States Department of Agriculture [SSS NRCS USDA] $2020 a$ and b). These are primarily encompassed by the Snakecreek fine sandy loam, typified as Coastal plains and drainageways environments. There are also smaller sections of the APE that fall under Edna loam or fine sandy loam that are found on coastal plans and flats (Mowery et al. 1960; Wheeler 1976).

\subsection{Natural Environment}

\subsubsection{Flora and Fauna}

The project area is located near the western edge of the Austroriparian biotic province and is situated in the Upland Prairies and Woods subregion of the Gulf Coast Prairies and Marshes Region (Abbott 2001). Evidence from pollen analysis in Central Texas suggests that, at least during the Late Pleistocene, the area may have been populated by vegetative species that were tolerant of a cold-weather environment. Climactic fluctuation during the Holocene would eventually result in a gradual trend towards warmer weather, similar to that seen today (Abbott 2001).

Late Pleistocene flora may have included populations of spruce, poplar, maple, and pine (Holloway et al. 1987) in an oak woodland environment that would eventually transition to an oak savanna in the late Holocene (Abbott 2001). Fauna during this time would include currently present species such as white-tailed deer and various smaller game, as well as bison, and, in localized areas, pronghorn sheep and the American alligator (Abbott 2001).

Table 2-1. Soils Recorded within the APE.

\begin{tabular}{|c|c|c|c|}
\hline Soil Type & Parent Material & Topographic Position & Comments \\
\hline $\begin{array}{c}\text { Snakecreek } \\
\text { fine sandy } \\
\text { loam }\end{array}$ & $\begin{array}{c}\text { Loamy sediments from Holocene } \\
\text { age alluvium }\end{array}$ & $\begin{array}{c}\text { Coastal plains and } \\
\text { drainageways }\end{array}$ & $\begin{array}{c}\text { Very deep, nearly level, somewhat } \\
\text { poorly drained }\end{array}$ \\
\hline $\begin{array}{c}\text { Edna loam or } \\
\text { fine sandy } \\
\text { loam }\end{array}$ & $\begin{array}{c}\text { Loamy sediments of the } \\
\text { Beaumont Formation of } \\
\text { Pleistocene age }\end{array}$ & Coastal plains and flats & $\begin{array}{c}\text { Very deep, nearly level, somewhat } \\
\text { poorly drained }\end{array}$ \\
\hline
\end{tabular}




\subsubsection{Climate}

The project area's proximity to the Gulf of Mexico tends to influence the temperature, rainfall, and relative humidity of the region. Winds usually trend from the southeast or east, except during winter months when highpressure systems can bring in polar air from the north. Average temperatures in the summer can reach well into the 90 s degrees Fahrenheit (30s degrees (elsius) and are often accompanied by equally high humidity. Although winter temperatures can reach into the low 30s degrees Fahrenheit (0 degrees Celsius), below freezing temperatures usually occur on only a few days out of every year and are typically restricted to the early morning hours. Rainfall is evenly distributed throughout the year, with an average monthly distribution ranging from between 43 centimeters (17 inches) to trace amounts; rainfall comes primarily from thunderstorms, which tend to be heavy but of short duration (Wheeler 1976:2).

\subsection{Land Use}

The APE has had limited use within the past hundred years (USGS 1915, 1950, 1955, $1971,2010)$. Land use in the area is largely residential, with neighborhoods surrounding the APE and small pockets of wooded areas interspersed along the banks of Buffalo Bayou. The bayou was channelized sometime between 1953 and 1958 (NETR 2020). A residential building between the bayou and Katy-Flewellen Road appears mapped by 1971 (USGS 1971). A borrow pit was excavated between the meanders of the bayou between 1983 and 1989 (Google Earth 2020; NETR 2020). 


\subsection{CULTURAL CONTEXT}

\subsection{Prehistoric Context}

Along the Upper Texas Coast, the Paleoindian period begins around 12,000 Before Present (B.P.) and ends near 9,000 B.P. (Aten 1983; Story 1990). This period is poorly represented in the archaeological evidence for the region (Aten 1983) and no sites for this period have been verified. Isolated artifacts include Clovis, Angostura, Scottsbluff, Meserve, Plainview, and Golondrina point types (Aten 1983). Sites from this stage would be either buried by alluvium or found in upland sites.

The Transitional Archaic period begins about 9,000 B.P. and ends around 7,500 B.P. (Aten 1983; Story 1990). This stage is also poorly represented in the archaeological work in the area but isolated finds of Bell/Calf Creek, EarlySide Notched, and Early Expanding Stemmed dart points are attributed to this time period. The Archaic stage is thought to include a shift towards a diet more geared towards plant processing but still includes hunting. Plant processing technology seen during the entire Archaic period includes stone-lined hearths and baking pits as well as milling tools (Story 1990). Groups began to travel over less of the landscape and population density seems to have risen.

Beginning at 7,500 B.P., and spanning 2,500 years (Aten 1983), the Early Archaic period in this region has not been well documented. The sites may have been destroyed or deeply buried (Aten 1983; Story 1990). In situ, Early Archaic remains have been found at the Addicks Reservoir as well as other localities in the area (Story 1990). Points from this period include Bell, Carrollton, Trinity, Wells, and Early Stemmed. It is possible that the Carrollton, Trinity, and Wells points continued to be used into the Middle Archaic (Patterson 1996).
The Middle Archaic period (5,000 to 3,000 B.P.) reveals the earliest surviving shell middens (Aten 1983). These middens contain remains of shellfish, such as oysters and estuarine clams, faunal material from terrestrial and aquatic vertebrates, and the earliest known human burials in the region (Aten 1983). Characteristic projectile points include Bulverde, Williams, Lange, and Pedernales types.

The Late Archaic period lasted from 3,000 to 2,000 B.P. and shows evidence for population increase (Aten 1983). By 2,500 B.P., the climate in this area was essentially like the modern climate. Ground-stone artifacts made from materials from southwestern Arkansas and found in context with human burials in cemeteries such as the Ernest Witte Site indicate the possibility of trade (Hall 1981). Projectile points differ from earlier periods in that they are corner-notched or expanding-stemmed forms, such as the Kent, Ellis, and Pontchartrain types. Other types can be found, such as the unnotched Pamillas. These types are thought to precede the Gary type, which can be found in the Late Prehistoric (Story 1990). During the Late Archaic, more utilitarian biface tools are prevalent as well as are bone tools. Late Archaic assemblages are very similar to the early part of the Late Prehistoric stage (Aten 1983).

The transition from the Late Archaic stage to the Late Prehistoric is indicated by the introduction of ceramics into the assemblage (Aten 1983). Cultural shifts during the Late Prehistoric include the possible adoption of a more sedentary lifestyle and major technological changes, such as sandy paste ceramics and late in the stage, the bow and arrow (Story 1990). The cultural tradition during the Late Prehistoric along the Upper Gulf Coast has been designated as Woodland. Story (1990) has suggested the use of the term Mossy Grove Tradition to define the cultural patterns of the region. The Trinity River seems to be a dividing line in this tradition with cultures east of the river being more similar to 
those in Lovisiana than to those west of Galveston Bay. The eastern tradition also seems to have begun earlier than that in the west, beginning about 2,000 B.P. and lasting 600 years (Aten 1983; Story 1990).

Story (1990) splits the Mossy Grove Tradition into five distinct time intervals on the coast while noting that only two are found inland. Aten (1983) defined these intervals for the area between the Brazos River and Galveston Bay as the Clear Lake (1,850-1,525 B.P.), Mayes Island (1,525-1,300 B.P.), Turtle Bay (1,300 950 B.P.), Round Lake (950-600 B.P.), and Old River (600-250 B.P.) periods based on ceramic styles. Only the Round Lake period is recognized by Aten for the West Bay-Brazos Delta due to the low artifact class diversity compared to areas east of Galveston Bay as well as a time discrepancy in which equivalent periods are later than those to the east (Aten 1983).

Early ceramics from this area are similar to the Tchefuncte period wares found near Sabine Lake and into Louisiana and include sandy paste varieties such as Mandeville Plain, Goose Creek Plain (Anahuac variety), and Tchefuncte Plain (Aten 1983; Story 1990). These early sites appear similar to pre-ceramic sites due to the low number of ceramic sherds found. The appearance of sandy paste and sand-tempering occurs about 1,900 B.P. with the $\mathrm{O}^{\prime} \mathrm{Neal}$ Plain (variety Conway) being a good example (Aten 1983). Rocker-stamped decorations, a distinctive marker for this period, are uncommon in the West Bay-Brazos Delta, as are incised wares (Aten 1983).

The Mayes Island period brought about the introduction of the bow and arrow, which was probably used along with the atlatl until the historic period (Aten 1983; Story 1990). The arrow points during this period included both notched and expanding-stemmed forms (Aten 1983; Story 1990).

Ceramic indicators for the Turtle Bay period include Goose Creek red-filmed along with other decorated ceramics, all of which are rare in the West Bay-Brazos Delta area. At the beginning of the Round Lake period, the earliest use of grog or large crushed ceramic particles as tempering agents is seen. Typical varieties include Baytown Plain (variety San Jacinto) and San Jacinto Incised. Along with these types, a reduction in Goose Creek types is seen. Aten (1983) describes this period as having an increase in population due to the larger number of sites in more specialized locations.

During the Old River period, a resurgence of Goose Creek ceramics is seen as the Baytown types decrease in popularity. Contact with Europeans begins near the end of this period, but visible changes in material culture are not seen until about A.D. 1750 along with a rapid decline in population (Story 1990).

\subsection{Historical Context}

Present-day Fort Bend County was established on December 29, 1837, from parts of earlier counties consisting of Austin, Brazoria, and Harrisburg. The town of Richmond, which had been incorporated in May of that same year, was voted the county seat by the citizens of the new county (Hardin 2002).

In 1821, the schooner Lively set sail from New Orleans and anchored at the mouth of the Brazos River. Of this first contingent of Austin's settlers, a small party continued 145 kilometers (90 miles) up the Brazos to a bend in the river. Here, in November 1822, a blockhouse was built. Other settlers followed and a small community that came to be referred to as Fort Bend grew around the blockhouse. Fort Bend was located on one of the primary fords of the Brazos River and as such, played a role in the troop movements of the Texas Revolution. The site was abandoned when Santa Anna's Mexican Army crossed the river en route to the battle of San Jacinto. When the area was resettled, the new community of Richmond was established (Leffler 2002). 
The first Texas land grant is reported to have been made in 1731 for land near San Antonio. The Mexican government continued the process after Spanish rule was toppled in 1821. The area of what is now Fort Bend County was originally settled in the 1820s as part of the land grant to Moses Austin by the Mexican government in 1821. Having died that same year, his son, Stephen F. Austin, was allowed to carry out the colonization. Of the 297 original grants to Austin, 53 were situated in present-day Fort Bend County (Hardin 2002).

Persons who received grants often had a say in the size, shape, and location of the parcel, with areas along streams and rivers the most soughtafter. After the Texas Revolution, the General Land Office (GLO) was established to manage land grants and surveys. Before new grants or amendments to old ones could take place, the GLO required new surveys accompanied by field notes, sketches, deeds, and other forms of documentation. Even so, the accuracy of some of the older property maps is quite flawed due to poor equipment, inconsistent units of measure, and dangerous frontier conditions (Jacobson 1992). As was customary by the Mexican government, the league was rectangular shaped with a quarter of it falling along the river. The original grant was written in Spanish and appears to have been measured in versa, the Spanish yard.

Buffalo Bayou was one of the centers of early Anglo-American settlement in colonial Texas. Communities like Lynchburg, Harrisburg, and Morgan's Point all emerged near the bayou in the early 1800s. The final battle for Texas Independence from Mexico was fought along the banks of the bayou where it meets the San Jacinto River. Houston's original port and docks are known as Allen's Landing and were established along Main Street where Buffalo Bayou and White Oak Bayou converge. The first wharves were opened in 1840 and the Port of Houston was established in 1841. For settlers in Fort Bend County, Buffalo Bayou was an important conduit of agricultural exports to the market, particularly sugar, cotton, and rice (Hardin 2002).

In 1853, the Buffalo Bayou, Brazos, and Colorado Railway proved a further boon to business connecting Stafford Point to Harrisburg. African slaves were essential to the plantation economy of the region and by the 1850s, outnumbered the white inhabitants of the county. Because of this economic reality, Fort Bend planters strongly supported the Southern secession and the Civil War (Hardin 2002).

The economy of Fort Bend in the nineteenth century focused on cotton, sugar, corn, and livestock production. In the 1890s, a onemillion-dollar sugar refinery was constructed in Sugar Land. The county also contains substantial amounts of oil, gas, and sulfur deposits, which have played a major role in the economic development of the area (Hardin 2002).

Buffalo Bayou has likewise served as an ecological role in delaying and moderating peak outflow of the river during large rainfall events. Extreme flooding between 1929 and 1935 led to a number of federally funded flood control projects in the Buffalo Bayou watershed. The Texas Legislature created the Harris County Flood Control District (HCFCD) in 1937, and over $\$ 35$ million federal, state, and county funds were put toward a drainage program. The western half of Harris County was still rural when the USACE constructed Barker Reservoir (1945) and Addicks Reservoir (1948). Six miles of Buffalo Bayou between present-day Highway 6 and Beltway 8 were channelized during the construction of these reservoirs. 


\subsection{FIELD METHODOLOGY}

This cultural resource investigation was designed to identify and assess new and previously recorded cultural resources that may be impacted by the proposed project. Desktop assessment and modeling were performed prior to initiating field investigations to better understand cultural, environmental, and geological settings. The results of the desktop assessment were then used to develop the field methodology.

\subsection{Site File and Literature Review}

The background literature search included a review of previously conducted cultural resource surveys in the vicinity of the proposed project area, and any historical documents pertaining to the history of the area. Site file research was performed to identify all previously recorded archaeological sites within a 1.6-kilometer (1mile) study radius of the project area and any recorded historic structures eligible for the National Register of Historic Places (NRHP) or State Antiquities Landmark (SAL) listing located adjacent to the project area. Site file research was done by reviewing records maintained by the Texas Archeological Research Laboratory in Austin, Texas, and by consulting the THC.

Historical topographic maps and aerial photographs were reviewed to identify any historic structures, residential, and other structures that might be located close to or within the project area. Historical maps of Texas and Texas counties were also reviewed in order to better understand the history of the region and to identify any potential historic trails and historic sites located or crossing the project area.

\subsection{Field Methods}

\subsubsection{Intensive Pedestrian Survey}

Subsurface testing included a combination of systematic shovel testing and judgement sample auger probing. Shovel testing was conducted at 60-meter (197-foot) intervals along two transects, one on each side of the bayou. Transect $A$ runs along the west bank; Transect $B$ runs along the east bank. Shovel tests were excavated in 10-centimeter (4-inch) levels at a minimum of 30 centimeters (12 inches) in diameter. All shovel tests were excavated to a maximum depth of 100 centimeters (39 inches), and selected tests were hand augured to deeper depths. Soils were screened through 6.4milliimeter ( $1 / 4$ inch) mesh or hand sorted if clay soils were encountered. The location of each test was recorded on ArcGIS Collector using an Eos Arrow Series Global Positioning System (GPS) unit. Shovel test and auger probe data included soil depth, color, texture, inclusions, and general notes of locations and evidence of disturbance. These descriptions followed the standards of Munsell (2013) and Vogel (2002). During reconnaissance, photographs were taken to document recent disturbances within the APE. The extent of these disturbances as well as the locations of existing sheet-pile piers were recorded on Collector.

\subsubsection{Site Delineation}

Close-interval shovel testing was conducted near the previously recorded site centroids for $41 F B 101$ and 41FB102. Near these locations, a series of shovel tests were excavated at 10meter (33-foot) intervals. At the bottom of at least half of these close-interval shovel tests, a hand auger was used to conduct deep testing to evaluate the extent of disturbances and the potential for deeply buried sites. Each auger test was excavated in 10-centimeter (4-inch) levels to a maximum depth of 150 -centimeters (59 inches) and screened through 6.4-millimeter ( $1 / 4$ inch) mesh or hand sorted if clay soils were encountered. 


\subsection{Curation}

No diagnostic or non-diagnostic artifacts were collected in the course of the current survey. As a project permitted through the THC; however, Gray \& Pape submitted project records to the Center of Archaeological Studies (CAS) at Texas State University. 


\subsection{RESULTS OF INVESTIGATIONS}

\subsection{Result of Site File and Literature Review}

The site file research revealed that five archaeological surveys, one cemetery, and four previously recorded archaeological sites are located within the 1.6-kilometer (1-mile) study radius surrounding the project area (Figure 1 1). None of these sites are currently listed as National Register properties; however, the NRHP status for three of the sites has yet to be determined. No Historic Landmarks or National Register Properties or Districts are located within or near the APE.

\subsubsection{Previously Recorded Surveys}

According to a search of the Texas Archeological Sites Atlas, three linear surveys and two area surveys have been conducted between 1985 and 2019 within the study radius (Table 5-1). None of these surveys overlap with the proposed project area.
In 1985, a linear survey which involved the Environmental Protection Agency (EPA) was conducted between Morton Road to the north and Interstate Highway $(\mathrm{IH}) 10$ West to the south. This survey was located within 0.89 kilometers ( 0.55 miles) of the APE and covered approximately 4.98 kilometers (3.09 miles) in total length. No sites were recorded during this investigation.

A linear survey from $\mathrm{IH} 10$ to US 90 was conducted by the Texas Department of Transportation (TxDOT) (Weir 1994). This survey was located within 1.3 kilometers $(0.8$ miles) of the APE and covered 0.92 kilometers (0.57 miles) in total length. No sites were recorded during this investigation.

In 2000, Moore Archaeological Consulting, Inc. (MAC, Inc.) conducted an area survey for the Buffalo Bayou-Poorman Tract project. This survey was located within 100 meters (328 feet) of the APE and covered approximately 8.9 hectares (22 acres). One new site, 41FB279, was recorded during this investigation.

Table 5-1. Previously Recorded Archaeological Projects Surrounding the Cane Island Branch Section of the Buffalo Bayou Project, Fort Bend County, Texas.

\begin{tabular}{|c|c|c|c|c|c|c|}
\hline $\begin{array}{c}\text { Survey } \\
\text { Type }\end{array}$ & $\begin{array}{c}\text { Investigating Firm/ } \\
\text { Agency }\end{array}$ & $\begin{array}{c}\text { Field } \\
\text { Work } \\
\text { Date }\end{array}$ & $\begin{array}{c}\text { TAC Permit } \\
\text { Number }\end{array}$ & $\begin{array}{c}\text { Report } \\
\text { Author }\end{array}$ & $\begin{array}{c}\text { Sponsoring } \\
\text { Agency }\end{array}$ & $\begin{array}{c}\text { Report } \\
\text { Published }\end{array}$ \\
\hline $\begin{array}{c}\text { Linear } \\
\text { Survey }\end{array}$ & EPA & 1985 & N/A & N/A & EPA & N/A \\
\hline $\begin{array}{c}\text { Linear } \\
\text { Survey }\end{array}$ & TxDOT & 1995 & N/A & Weir, Frank & N/A & $01 / 01 / 1995$ \\
\hline $\begin{array}{c}\text { Area } \\
\text { Survey }\end{array}$ & MAC, Inc. & 2000 & N/A & N/A & $\begin{array}{c}\text { I-Ten Poorman } \\
\text { Investments, Inc. }\end{array}$ & N/A \\
\hline $\begin{array}{c}\text { Linear } \\
\text { Survey }\end{array}$ & $\begin{array}{c}\text { SWCA } \\
\text { Environmental } \\
\text { Consultants }\end{array}$ & 2016 & 7828 & Bettis, Allen & TxDOT & $06 / 23 / 2017$ \\
\hline $\begin{array}{c}\text { Area } \\
\text { Survey }\end{array}$ & $\begin{array}{c}\text { Blanton \& } \\
\text { Associates, Inc. }\end{array}$ & 2019 & 8783 & $\begin{array}{c}\text { Burden, A. S. } \\
\text { \& J. Sanchez }\end{array}$ & TxDOT & $05 / 2019$ \\
\hline
\end{tabular}


On December 16, 2016, SWCA Environmental Consultants (SWCA) conducted a linear survey along Farm-to-Market (FM) 1463 between IH 10 and FM 359 for the purpose of improving and widening the roadway (Bettis 2017). This survey was located within 0.76 kilometers $(0.47$ miles) of the APE and covered 10.9 kilometers (6.8 miles) in total length. No sites were recording during this investigation.

On February 25, 2019, Blanton \& Associates, Inc. conducted an area survey of 2.6 hectares (6.5 acres) of new ROW for a new detention pond between the Willow Fork of Buffalo Bayou and FM 1463 (Burden \& Sanchez 2019). This survey was located within 1.26 kilometers $(0.78$ miles) of the APE. No sites were recorded during this investigation.

\subsubsection{Previously Recorded Cemeteries}

Also known as the Stockdick or Antioch Cemetery, the Katy Community Cemetery is an active Texas Historic Cemetery located approximately 1.28 kilometers $(0.80$ miles $)$ northwest of the APE between I-10 and Stockdick Road. The Antioch Missionary Baptist Church purchased the 0.4-hectar (1-acre) of land in 1929 from John Stockdick for \$37.50. It includes at least 65 graves with the earliest burial dated to the year of sale (Katy Magazine 2020).

\subsubsection{Previously Recorded Archaeological Sites}

The site file research revealed that four prehistoric archaeological sites are located within the study radius (Table 5-2). Two of these sites are located within or immediately adjacent to the APE.

Site 41 FB 101 is a Late Archaic site recorded on January 7, 1985, by Bruce Duke following the excavation of a borrow pit on privately owned land (Duke 1985). The site centroid is mapped in an oxbow immediately east of the APE along Buffalo Bayou. Mr. Duke was granted permission by Shefman Investments, Inc. to collect surface materials after excavation had disturbed the site; however, no shovel testing or other subsurface testing was allowed. Artifacts collected from the surface included three Goose Creek plainware sherds, one Goose Creek incised sherd, three Kent projectile points, a stem from a large projectile point, several small pebbles, and more than 300 pieces of chert debitage. These materials were inferred to have derived from a series of small middens along Buffalo Bayou. The NRHP status of this site is currently undetermined (Texas Historic Sites Atlas 2020).

Table 5-2. Previously Recorded Cultural Resources Surrounding the Cane Island Branch Section of the Buffalo Bayou Project, Fort Bend County, Texas.

\begin{tabular}{|c|c|c|c|c|}
\hline $\begin{array}{l}\text { Trinomial/ } \\
\text { THC } \\
\text { Designation }\end{array}$ & Site Type & $\begin{array}{l}\text { Temporal } \\
\text { Affiliation }\end{array}$ & $\begin{array}{c}\text { Original Recorder(s) and } \\
\text { Date }\end{array}$ & $\begin{array}{c}\text { NRHP } \\
\text { Status/Recommendations }\end{array}$ \\
\hline$* 41 \mathrm{~F} 101$ & Midden & Late Archaic & Duke, Bruce 01/07/1985 & $\begin{array}{l}\text { Undetermined / } \\
\text { Excavation } \\
\text { recommended }\end{array}$ \\
\hline *41FB102 & Pimple Mound & Woodland & Duke, Bruce 02/26/1985 & $\begin{array}{l}\text { Undetermined / } \\
\text { Excavation } \\
\text { recommended }\end{array}$ \\
\hline $41 \mathrm{FB} 129$ & Midden & $\begin{array}{c}\text { Woodland-Late } \\
\text { Prehistoric }\end{array}$ & Duke, Bruce 1986 & Ineligible \\
\hline $41 F B 279$ & Lithic Scatter & Prehistoric & Terneny, Tiffany 2000 & $\begin{array}{l}\text { Undetermined / No } \\
\text { further work }\end{array}$ \\
\hline
\end{tabular}

*Within or immediately adjacent to the APE. 
Site $41 \mathrm{FB} 102$ is a Woodland site recorded on February 26, 1985, by Bruce Duke (Duke 1985). The site was located on a fine sandy loam mound measuring 4.6 to 6.1 meters (15 to 20 feet) in diameter. The site centroid is mapped within the APE along the east bank of Buffalo Bayou reportedly where an assemblage of lithic and ceramic artifacts was observed eroding out of the bluff overlooking the bayou approximately 45 centimeters ( 18 inches) below the surface. Artifacts observed and collected included one Goose Creek plainware sherd, one complete projectile point, and several pieces of chert debitage. No shovel testing or other subsurface testing was conducted during the initial investigation. The NRHP status of this site is currently undetermined (Texas Historic Sites Atlas 2020).

Site 41FB129 is a Woodland-Late Prehistoric midden recorded on March 16, 1986, by Bruce Duke (Duke 1986). The site was located along the west bank of the Willow Fork of Buffalo Bayou. No shovel testing or other subsurface testing was conducted during the initial investigation; however, an assemblage of lithic and ceramic artifacts that were eroding out of the bank was collected. These materials included several pieces of chert debitage, three Goose Creek sherds, one Scallorn projectile point, and two broken bifaces. This site was determined ineligible for the National Register by the State Historic Preservation Office (SHPO) on November 15, 2000 (Texas Historic Sites Atlas 2020).

Site 41FB279 is a buried prehistoric lithic scatter. The site was recorded between September 8 and September 12, 2000, by Tiffany Terneny with MAC, Inc. during the Buffalo Bayou Poorman-Tract project (Terneny 2000). The site was located along the north bank of the Willow Fork of Buffalo Bayou between 40 and 80 centimeters $(16$ and 32 inches) below the surface. The only artifacts from this site were several pieces of chert debitage. The NRHP status of this site is currently undetermined (Texas Historic Sites Atlas 2020).

\subsection{Results of Field Investigations}

A total of 41 shovel tests were excavated throughout the APE to a maximum depth of 100 centimeters (39 inches) (Figure $5-1$; see Appendix for a complete table of all shovel test and auger probe profiles). Eight of these shovel tests were further probed with a hand auger to a depth of 150 centimeters (59 inches) (Figure 5-1; Appendix). Across the majority of the APE, shovel testing showed evidence of disturbances in the soil profiles down to 100 centimeters (39 inches); intact sediments were noted at the edge of the APE in isolated areas. A representative soil profile from Shovel Test A12 included four strata (Figure 5-2). Stratum I from 0 to 20 centimeters ( 0 to 8 inches) below the surface was a mixture of gray (7.5YR 5/1) and light brown (7.5YR 6/3) loam and sand. Stratum II from 20 to 40 centimeters (8 to 16 inches) below the surface was very pale brown (10YR 7/4) mottled with brownish yellow (10YR 6/8) disturbed loamy sand. Stratum III from 40 to 50 centimeters ( 16 to 20 inches) below the surface was gray (7.5YR 5/1) disturbed sandy clay loam. Stratum IV from 50 to 100 centimeters (20 to 39 inches) below the surface was pink (7.5YR 7/3) mottled with light brown (7.5YR 6/4) sandy loam.

During reconnaissance, an initial attempt was made to relocate previously recorded Sites 41FB101 and 41FB102 through surface inspection and limited shovel testing across the APE along both sides of Buffalo Bayou. Recent disturbances were observed in the form of mechanical excavation along the channel slopes, the dumping of spoil across the surface of the two-track right-of-way (ROW) along the bayou, and the active installation of sheet piling These disturbances were photographed and mapped (Figure 5-1). 


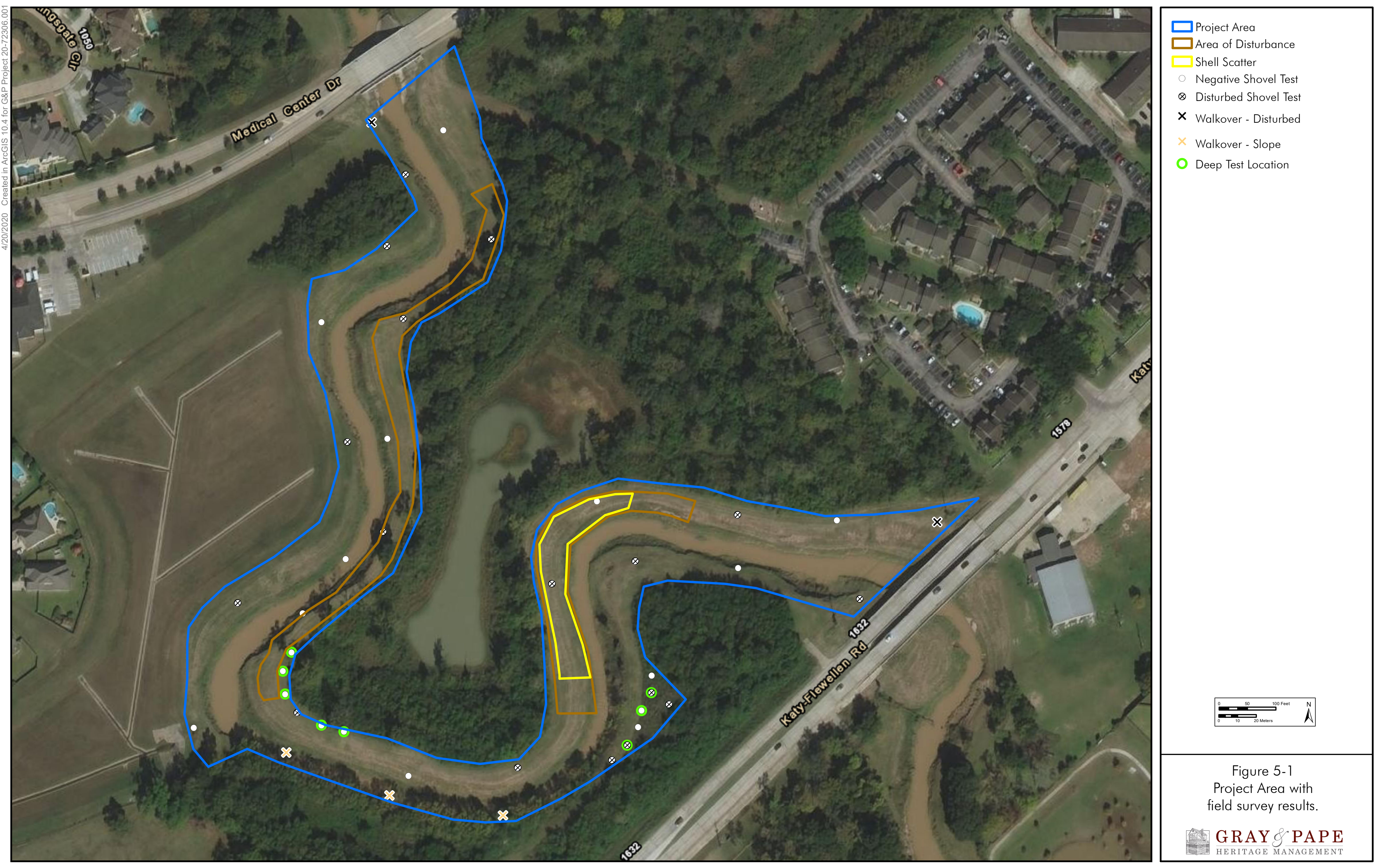



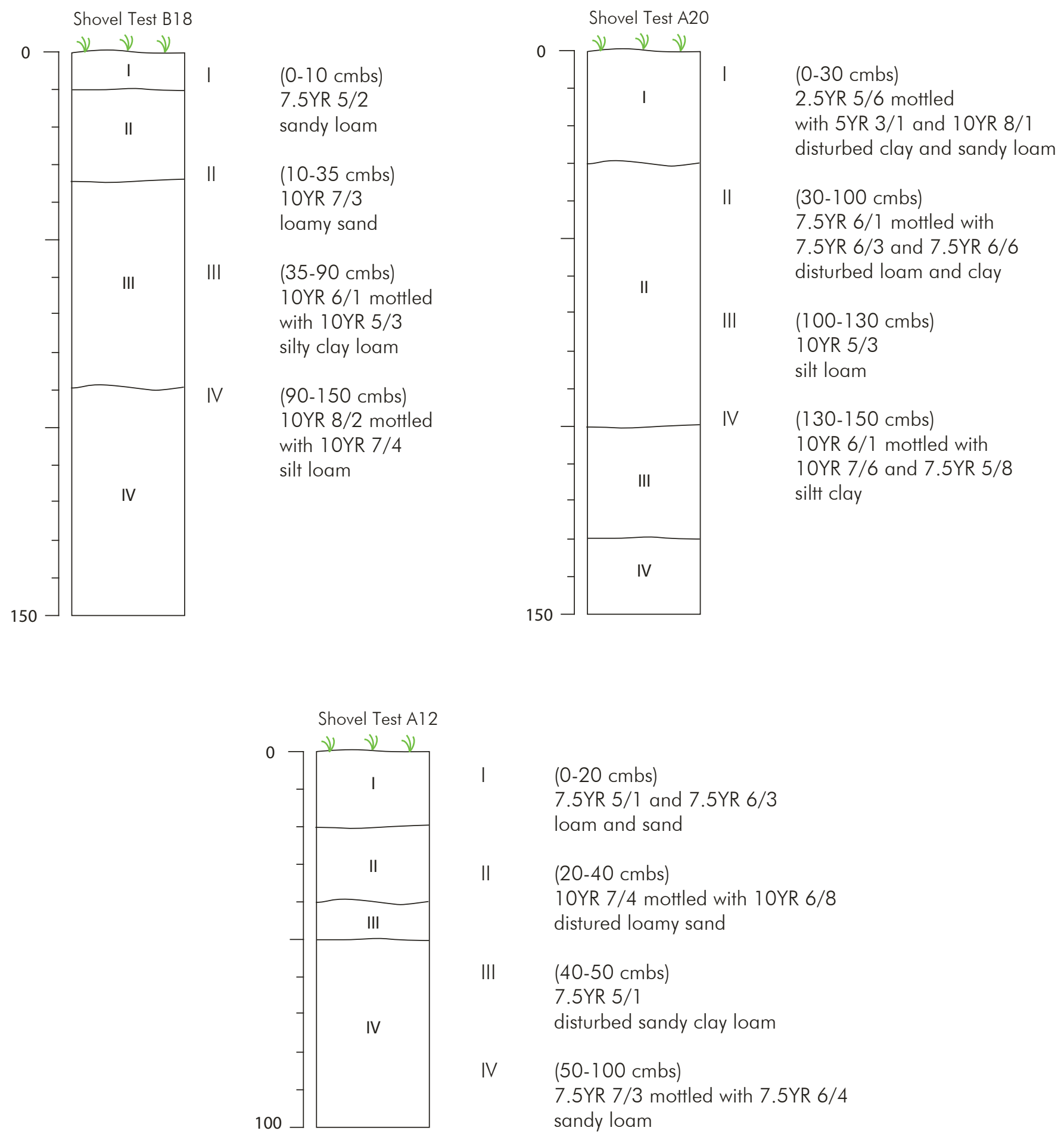

Representative shovel test profiles. 
Rangia shell $(n=8)$, including whole (closed) specimens and half shell, were observed on the surface in an area recently disturbed by heavy machinery. The shells were located east of Site 41 FB101 along the two-track ROW and slope of the east bank of Buffalo Bayou (Figure 5-3). The majority of them were smaller than 3 centimeters (1.2 inches), with one whole specimen measuring approximately 6 centimeters (2.4 inches). The surface and subsurface inspection in the immediate area of these specimens failed to find evidence of associated cultural features or artifacts on the surface or in a buried context. A variety of modern bricks and brick fragments were also observed along the inner slopes of the east bank near the shell scatter. These same materials were later observed among the variety of riprap materials along the west bank of the bayou west of Site 41FB102 near a residential property immediately adjacent to the APE (Figure 5-4). No additional cultural materials were observed on the surface with the exception of modern debris including plastics and aluminum cans.

The close-interval shovel tests along the silt fencing at the edge of the APE and near previously recorded Site 41FB101 (Figure 5-5) showed soils that appeared to be intact. A representative soil profile from Shovel Test B 18 included four strata (Figure 5-2). Stratum I from 0 to 10 centimeters ( 0 to 4 inches) below the surface was brown (7.5YR 5/2) sandy loam. Stratum II from 10 to 35 centimeters (4 to 14 inches) below the surface was very pale brown
(10YR 7/3) loamy sand. Stratum III from 35 to 90 centimeters (14 to 35 inches) below the surface was gray $(10 Y R$ 6/1) mottled with brown (10YR 5/3) silty clay loam. Stratum IV from 90 to 150 centimeters ( 35 to 59 inches) below the surface was very pale brown (10YR 8/2) mottled with very pale brown (10YR 7/4) silt loam.

Near 41FB102 at the edge of the APE (Figure 5-6), the close-interval shovel tests showed severe disturbances down to approximately 100 centimeters (39 inches); however, soils encountered with the auger probe did suggest the potential for intact soils below this depth. A representative soil profile from Shovel Test A20 included four strata (Figure 5-2). Stratum I from 0 to 30 centimeters ( 0 to 12 inches) below the surface was a mixture of red $(2.5 Y R 5 / 6)$, very dark gray (5YR 3/1) and white (1OYR 8/1) disturbed clay and sandy loam. Stratum II from 30 to 100 centimeters (12 to 39 inches) below the surface was a mixture of gray $(7.5 \mathrm{YR} 6 / 1)$, light brown (7.5YR 6/3) and reddish yellow (7.5YR 6/6) disturbed loam and clay. Stratum III from 100 to 130 centimeters (39 to 51 inches) below the surface was brown (10YR 5/3) silt loam. Stratum IV from 130 to 150 centimeters (51 to 59 inches) below the surface was gray (10YR 6/1) mottled with yellow (10YR 7/6) and strong brown (7.5YR 5/8) silty clay.

Sites 41FB101 and 41FB102 could not be relocated within the APE. No historic or prehistoric artifacts or cultural features were identified as a result of this survey. 


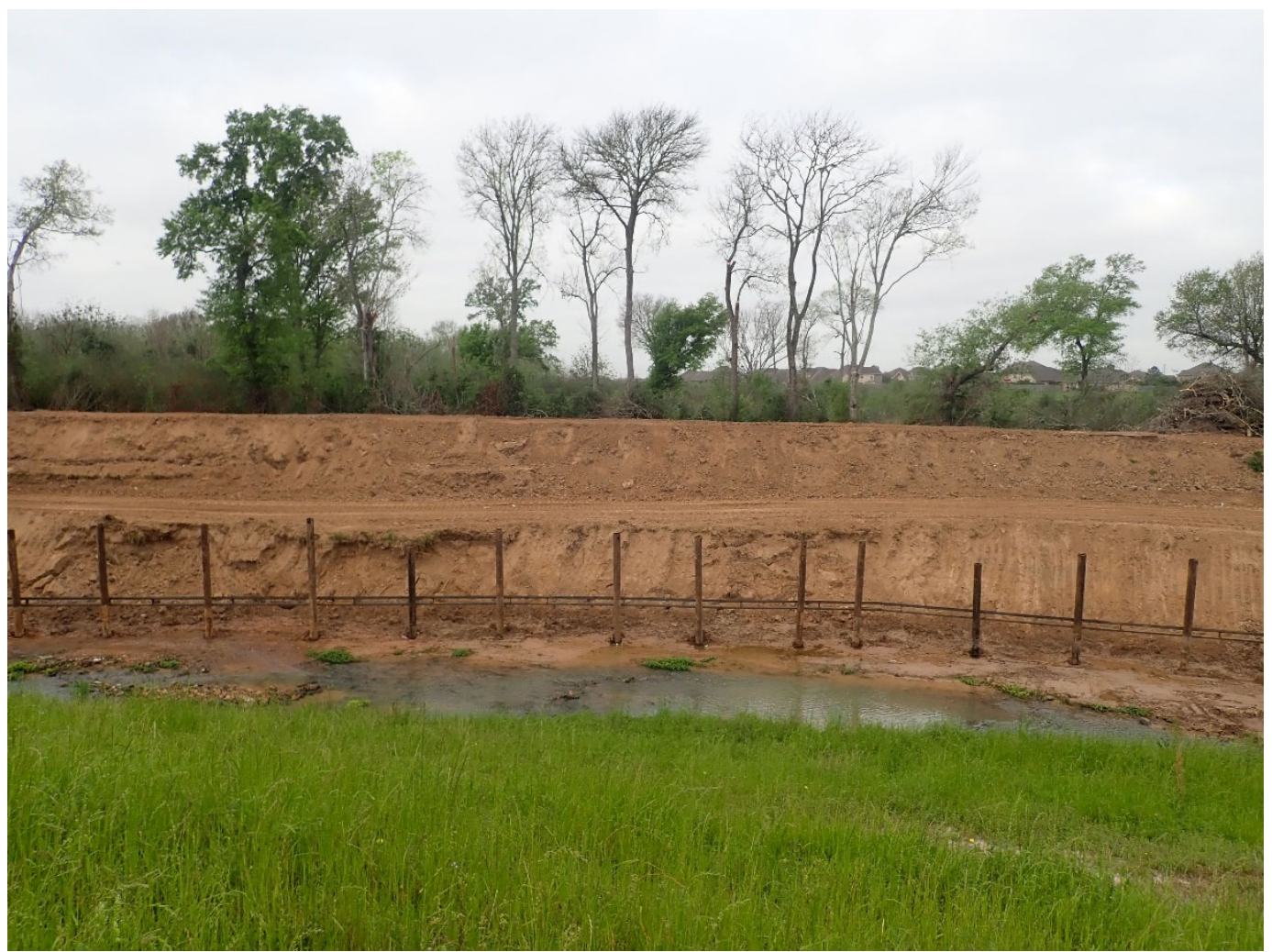

Figure 5-3. Recent disturbance and construction along Buffalo Bayou near shell scatter, view is facing west.

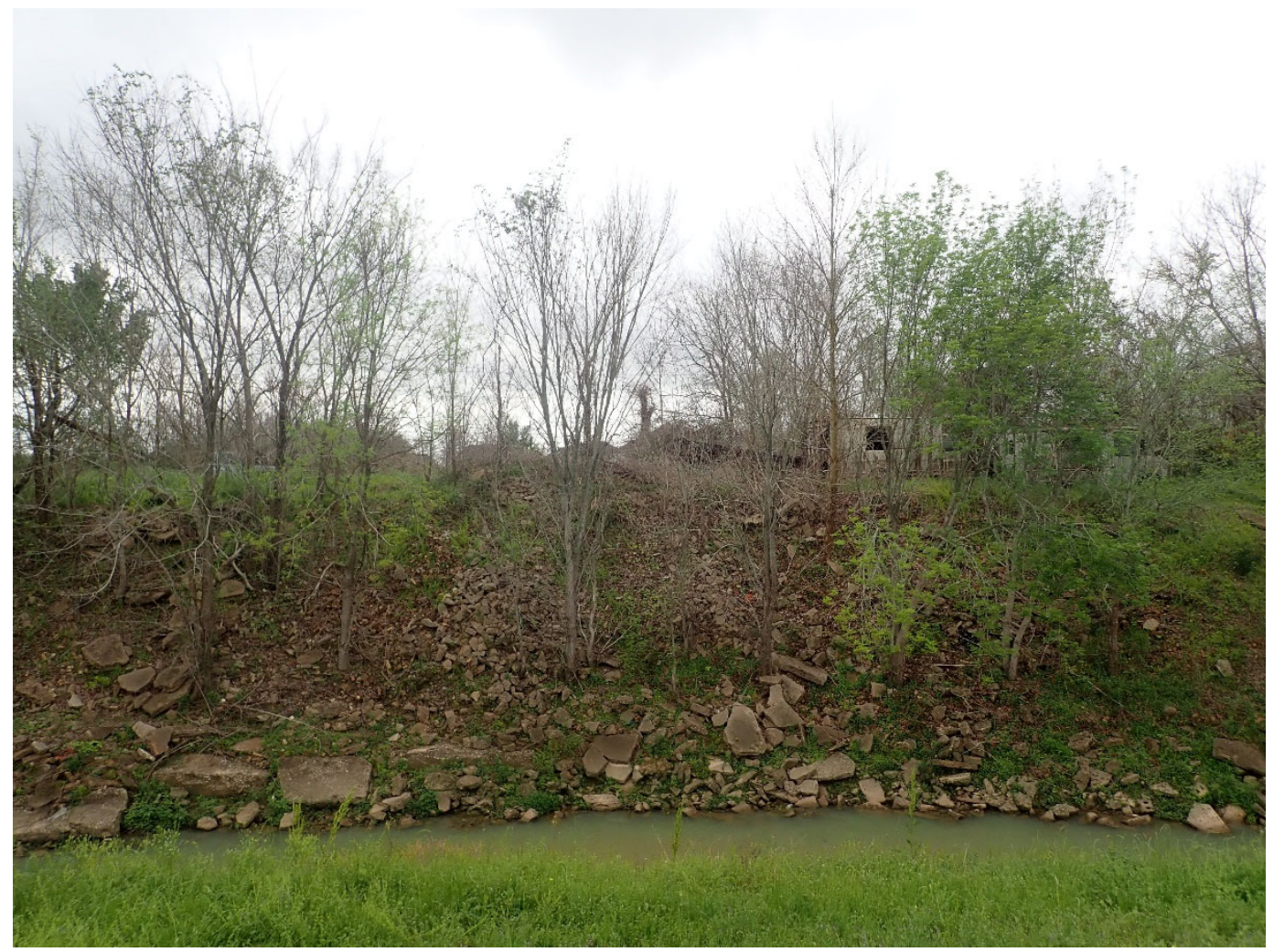

Figure 5-4. Residential property and riprap along Buffalo Bayou, view is facing southwest. 


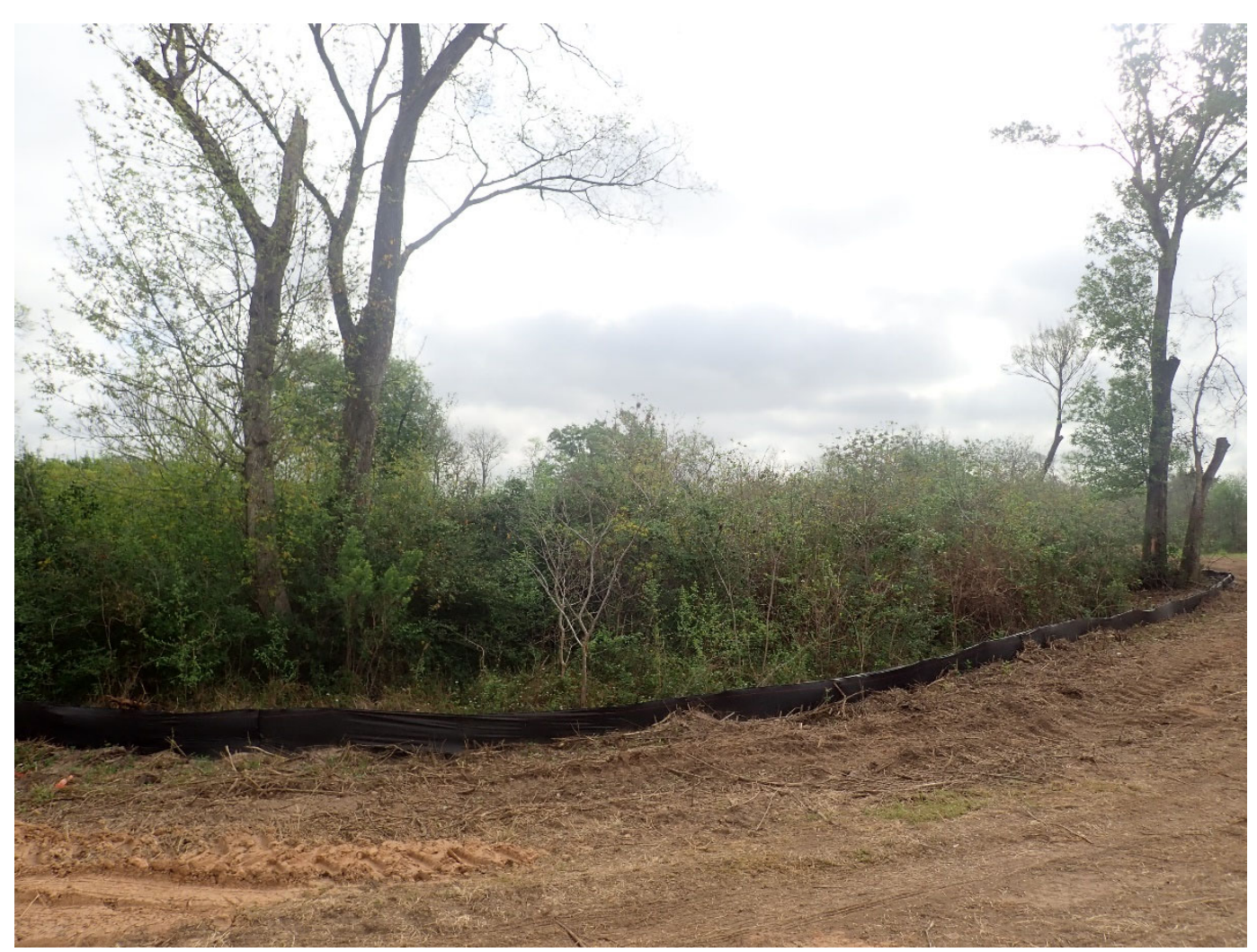

Figure 5-5. Overview of Site 41FB101 centroid location beyond silt fencing. View is facing east.

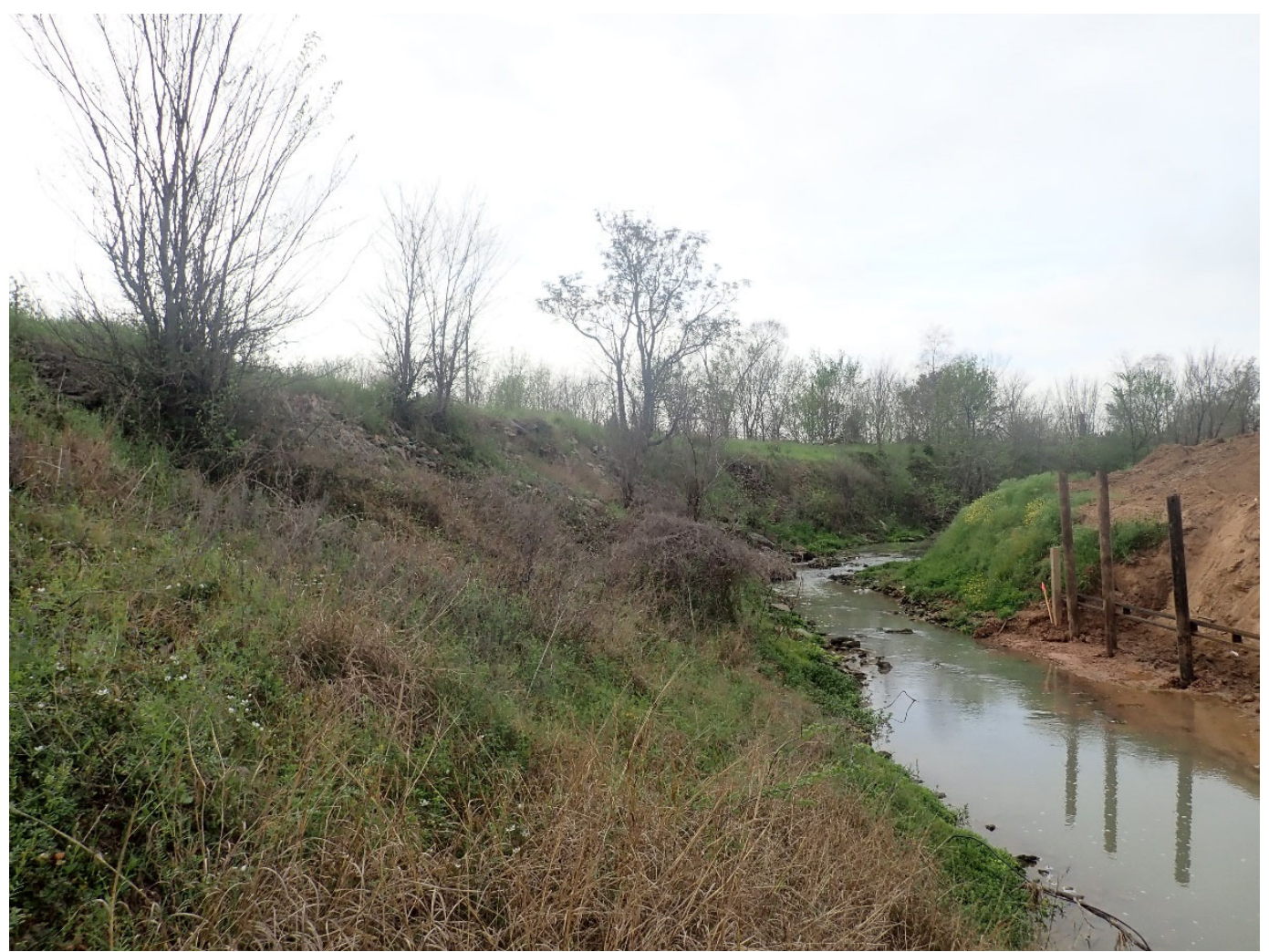

Figure 5-6. Overview of riprap along channelized bayou and Site 41 FB102 centroid. View is facing southeast. 


\subsection{CONCLUSIONS AND RECOMMENDATIONS}

In March 2020, Gray \& Pape conducted an intensive pedestrian cultural resources survey on property subsuming a total of approximately 0.93 kilometers $(0.58$ miles $)$ along Buffalo Bayou between Katy-Flewellen Rd. and Kingsland Blvd. The maintenance corridor will be 30 to 60 meters (98 to 196 feet), these dimensions defined the archaeological APE. The goal of this study was to assist Fort Bend County, the THC, and the Lead Federal Agency in determining whether or not intact cultural resources are present within areas for construction, and if so to provide management recommendations for these resources.

The site file research revealed that five archaeological surveys, one cemetery, and four previously recorded archaeological sites are located within the 1.6-kilometer (1-mile) study radius surrounding the project area. None of these sites are currently listed as National Register properties; however, the NRHP status for three of the sites has yet to be determined. No Historic Landmarks or National Register Properties or Districts are located within or near the APE.

Fieldwork was conducted between March 12 and March 16, 2020 and required approximately 40-person hours to complete. Subsurface testing included a combination of systematic shovel testing and judgement sample auger probing. At the beginning of the survey, an initial attempt was made to relocate previously recorded Sites 41FB101 and $41 F B 102$ through surface inspection and limited shovel testing across the APE along both sides of Buffalo Bayou. Recent disturbances from mechanical excavation along the channel slopes, the dumping of spoil across the surface of the two-track ROW along the bayou, and the active installation of sheet piling were photographed and mapped.

During the initial reconnaissance, Rangia shells were observed on the surface along the two- track ROW and slope of the east bank of Buffalo Bayou. Gray \& Pape was unable to find evidence of associated cultural features or artifacts on the surface or in a buried context in the immediate area surrounding the shell. A variety of modern bricks and brick fragments were also observed along the inner slopes of the east bank near the shell scatter. These same materials were later observed among the variety of riprap materials along the west bank of the bayou west of Site 41FB102 near a residential property immediately adjacent to the APE. With the exception of modern debris, no additional cultural materials were observed on the surface.

Gray \& Pape is not recommending a site designation for the Rangia shell or brick scatter observed during the survey for the foregoing reasons: 1) there were no intact, buried deposits or features found; 2) there was no material that could be positively identified as artifacts; 3 ) the bricks observed were modern and likely deposited by landowners in attempts to prevent erosion; 4) the size, quantity, and inclusion of whole Rangia identified on the surface appear to be natural occurrences as opposed to the remains of an archaeological deposit or feature; and 5) it is impossible to determine the original location of the shell specimens at this time.

The centroid for Site 41FB101 is mapped approximately 10 meters (33 feet) outside of the existing easement on privately-owned land. Gray \& Pape was unable to find evidence of this site within the $A P E$, and due to private property concerns, did not investigate outside of the APE. Close-interval shovel testing and auger probing near previously recorded Site 41FB101 did show soils that appeared to be intact.

The centroid for Site $41 \mathrm{FB} 102$ is mapped within the APE along the east bank of Buffalo Bayou reportedly where an assemblage of lithic and ceramic artifacts was observed eroding out of the bluff overlooking the bayou approximately 
45 centimeters (18 inches) below the surface. Close-interval shovel testing nearby showed severe disturbances down to approximately 100 centimeters (39 inches); however, soils encountered with the auger probe did suggest the potential for intact soils below this depth.

Sites 41FB101 and 41FB102 could not be relocated within the APE during the surface inspection, shovel testing, or auger probing. No other historic or prehistoric artifacts or cultural features were identified as a result of this survey.

Based on the results of this investigation, Sites $41 \mathrm{FB101}$ and 41FB102 do not appear to extend into the existing easement belonging to the Fort Bend County Drainage District. Instead, both sites appear to be located on private property outside of the project APE. As such, these sites have not been evaluated for National Register eligibility, but Gray \& Pape recommends that there will be no direct impact to these sites. It is also recommended that because the majority of project impacts will occur within sediments that have been repeatedly impacted by past channelization activities, the potential to identify intact, significant cultural resources is low. Gray \& Pape recommends that the project be allowed to proceed as currently planned. As a protective measure during construction, high-visibility temporary fencing should be installed against the edge of the APE in the vicinity of the two known sites. No additional cultural resources activities are recommended unless project plans change. 


\subsection{REFERENCES CITED}

Abbott, James $T$.

2001 Houston Area Geoarcheology: A Framework for Archeological Investigation, Interpretation, and Cultural Resource Management in the Houston Highway District. Texas

Department of Transportation, Environmental Affairs Division.

Aten, Lawrence $\mathrm{E}$.

1983 Indians of the Upper Texas Coast. Academic Press, New York.

Barnes, V.E.

1982 Geologic Atlas of Texas, Beaumont Sheet, revised. Bureau of Economic Geology, The University of Texas at Austin.

Bettis, Allen

2017 Archaeological Intensive Survey of Farm-to-Market Road 1463, Fort Bend County. Prepared by SWCA Environmental Consultants. Prepared for TxDOT.

Burden, Adrea Stahman and Joseph Sanchez

2019 Intensive Archaeological Survey: FM 1463 Detention Pond, Fort Bend County, Texas. Prepared by Blanton \& Associates, Inc. Prepared for TxDOT.

Cox, Betty Greenawalt 2002 The Handbook of Texas Online. MISSOURI CITY, TEXAS.

http://www.tsha.utexas.edu/handbook/online/articles/view/MM/hem6.html. Accessed April 2020.

Duke, Bruce

1985 Archaeological Site Forms (41FB101, 41FB102, 41 FB129). Atlas Map. Restricted Access. Accessed April 2020.

Google, Inc. (Google)

2020 Google Earth Aerial Imagery: 1944, 1978, 1989, 1995, 2002-2017. Accessed April 2020.

Hall, G.D.

1981 Allen's Creek: A Study in the Prehistory of the Lower Brazos River Valley, Texas. Research Report 61. Austin: Texas Archeological Survey, University of Texas at Austin.

Holloway, R. G., L. M. Raab, and R. Stuckenrath

1987 Pollen Analysis of Late Holocene Sediments from a Central Texas Bog. Texas Journal of Science 39: 71-79.

Hardin, S.

2002 Fort Bend County. The Handbook of Texas Online.

http://www.tsha.utexas.edu/handbook/online/articles/view/FF/hcf7.html. Accessed April 2020. 
Jacobson, Pauline

1992 The Evolution of Texas Land Surveys. Presented to the AM/FM/GIS Conference Dallas, Texas, October 29, 1992 for TOBIN International, Ltd.

Katy Magazine

2020 Katy Community Cemetery Received Historic Designation. The Online Resource Directory

for Katy, Texas. https://www.katymagazine.com/katy-community-cemetery-received-historicdesignation/

Leffler, J.

2002 Richmond, Texas. The Handbook of Texas Online.

http://www.tsha.utexas.edu/handbook/online/articles/view/RR/hfr4.html [Accessed April 2020.]

Mowery, Irvin C., Gordon S. McKee, Francisco Matanzo, and Everett Francis

1960 Soil Survey of Fort Bend County. Texas United States Department of Agriculture Soil

Conservation Service, Washington, D.C.

Munsell Soil Color Charts

2013 Revised Edition. Macbeth Division of Kollmorgan Instruments Corporation.

Nationwide Environmental Title Research (NETR)

2020 Historic Aerials (1953, 1958, 1964, 1970, 1973,1981, 1982, 1983, 1995). Available

URL: https://www.historicaerials.com/viewer. Accessed April 2020.

Soil Survey Staff, Natural Resources Conservation Service, United States Department of Agriculture (SSS NRCS USDA)

2020a Official Soil Series Descriptions [Online WWW]. Available URL: http://soils.usda.gov/soils/technical/classification/osd/index.html" Accessed April 2020.

2020b Web Soil Survey. Available URL:

http://websoilsurvey.nrcs.usda.gov/app/WebSoilSurvey.aspx. Accessed April 2020.

Story, Dee Ann

1990 Cultural History of the Native Americans. In The Archeology and Bioarcheology of the Gulf Coastal Plain: Volume 1, by Dee Ann Story, Janice A. Guy, Barbara A. Burnett, Martha Doty Freeman, Jerome C. Rose, D. Gentry Steele, Ben W. Olive, and Karl J. Reinhard, pp. 163-366. Arkansas Archeological Survey Research Series, No. 38. Fayetteville, Arkansas.

Terneny, Tiffany

2000 Archaeological Site Form (41FB279). Atlas Map. Restricted Access. Accessed April 2020.

Texas Historic Sites Atlas

2020 Atlas Map. Restricted Access. Accessed April 2020.

United States Geologic Survey (USGS)

1915 Katy, TX 7.5 Minute Quadrangle Topographic Map, 1:24,000.

1955 Brookshire, TX 15 Minute Quadrangle Topographic Map, 1:62,500

1971 Katy, TX 7.5 Minute Quadrangle Topographic Map, 1:24,000

2010 Katy, TX 7.5 Minute Quadrangle Topographic Map, 1:24,000. 
Vogel, Gregory

2002 A Handbook of Soil Description for Archeologists. Arkansas Archeological Survey Technical Paper 1 1. Published by Arkansas Archeological Survey.

Wheeler, Frankie F.

1976 Soil Survey of Harris County, Texas. United States Department of Agriculture - Soil Conservation Service, Washington D.C.

Weir, Frank

1994 Archaeological Resources Survey Report: FM 1463, from IH 10 to US 90, Fort Bend County. Texas Department of Transportation, Austin, Texas.

Young, Steven C., Ph.D., P.E., P.G., Trevor Budge, Ph.D., Paul R. Knox, P.G., Robert Kalbouss, Ernie Baker, P.G., Scott Hamlin, Ph.D., P.G., Bill Galloway, PhD., P.G., and Neil Deeds, Ph.D., P.E.

2010 Hydrostratigraphy of the Gulf Coast Aquifer from the Brazos River to the Rio Grande. Texas Water Development Board, Austin. 


\title{
APPENDIX:
}

SHOVEL TEST LOG

\author{
REMOVED FROM PUBLIC COPY
}

